he demonstrated that, in the hands of a skilled researcher, the interaction of Latin American studies with empirical political theory enriches both.

Bob never gave up, even when health prevented him from conducting field research. He turned instead to a broad, comparative analysis of some of the big questions. Bob was a man of high integrity and great courage. He leaves behind his wife, Mary, many friends, and more than a generation of grateful undergraduate and graduate students. He will be sorely missed.

John S. Ambler Rice University

\section{Ferdinand Aloys Hermens}

Ferdinand A. Hermens was born on December 20, 1906, in Nieheim, Germany, and died on February 2, 1998, in Rockville, Maryland. He was awarded the Diploma in Economics at the University of Bonn in 1928 and the doctorate three years later. His research on anti-parliamentary parties, study abroad in Rome and Paris, and publications in the areas of political sociology and representative institutions during the period 1930-33 made him persona non grata to the newly empowered National Socialist regime in Germany. He was compelled to emigrate, first to England, where he was a Research Fellow at the London School of Economics, and then to the United States, where he accepted a position as assistant professor of economics at The Catholic University of America in Washington, DC, 1935-38. He then moved to Indiana as an associate professor of politics at Notre Dame University, where he was named professor of politics in 1945 .

Ferdinand Hermens' works on the inter-relations of political and economic institutions continued throughout his life and were published mainly in Austria, Germany, and France. He became well known in the United States with the 1941 publication of Democracy or Anarchy? A Study of Proportional Representation, with an Introduction by Karl Friedrich. Work on the political consequences of constitutional forms, and above all the modes of parliamentary representation, dominated his research and writing for the remainder of his life and is, perhaps, most comprehensively treated in The Representative Republic (1958), published in German as Verfassungslehre (Frankfurt, 1964). Italian and Hebrew translations also appeared in 1968.

During and after World War II, Ferdinand Hermens was active in helping lay the groundwork for the democratic reconstitution of Europe and especially of Germany. The Tyrants' War and the Peoples' Peace, with an Introduction by R.M. MacIver, appeared in 1944; Democracy or Anarchy appeared in German translation in 1951. As a U.S. State Department Specialist/Adviser, he provided counsel and analysis relevant to the constitution of the German Federal Republic and its role in the emerging European and North Atlantic communities. He served as visiting professor at the universities of Münster and Bonn in 1948 and the University of Munich in 1953-54.

He left Notre Dame in 1959 to accept an appointment as professor of political science and director of seminar for political science at the University of Köln, from which he retired in 1972. He was also director of the Research Institute for Political Science and European Questions, 1960-72. While at Köln he directed some 30 published Ph.D. dissertations as well as numerous Diploma theses, and edited the following series:

\section{Kölner Schriften zur Politischen Wissenschaft}

\section{Demokratie und Frieden}

\section{Demokratische Existenz Heute}

\section{Verfassung und Verfassung- swirklichkeit}

In addition to numerous articles and book chapters touching on "political form," electoral systems, and the relations of class, economic, and political institutions, Ferdinand Hermens served on the German Ministry of Interior Advisory Committees on Electoral Systems (1954, 196768 ) and as a constitutional consul- tant in Israel, Ireland, Sri Lanka, Trinidad, and Tabago. The United States Information Agency sponsored a lecture trip to Spain, Germany, and Italy in 1978 and he gave testimony before the U.S. Senate Committee on the Judiciary regarding the nomination and election of the president and vice-president $(1949,1955)$ and before the Joint Economic Committee on "Divided Powers and Economic Policy."

On his retirement, Professor Hermens was awarded the Grosses Verdienstkreuz der Bundesrepublik (1972) and spent the following academic year as a Fellow of the Woodrow Wilson International Center for Scholars. He was research professor at American University, Washington, DC, from 1977 to 1989 , and a visiting scholar at The Catholic University of America from 1989 to 1998 . He continued his research and writing until the week of his death from cancer. His library was bequeathed to Catholic University's Mullen Library, whose archival collection is the repository for his papers and other biographic materials. He is interred at Mount Olivet Cemetery, Washington, DC, and survived by his wife of 60 years, Mary Ruth Roberts Hermens; their daughter, Mary Theresa Hardering of Miami; and a grandson.

Charles R. Dechert

The Catholic University of America

\section{Darrell P. Hammer}

Darrell P. Hammer, our friend, mentor, and colleague, died on March 25, 1998, in Bloomington, Indiana. He was 67 years old; we had expected to have him with us much longer.

Darrell was Professor Emeritus of Political Science at Indiana University, and had retired in 1996 after a long and productive career in the field of Soviet, and then Russian, politics. He was born in Burlington, Iowa, on November 18, 1930, and earned a bachelor's degree from Wichita State University in 1952 . He then moved on to the University of Washington, from which he received his master's degree in 1954, and he earned his doctorate from Columbia University in 1962. His training in 
Soviet Studies was interrupted by service in the United States Air Force from 1957 to 1959; he retired from the Air Force Reserve with the rank of captain in 1967.

Darrell joined the faculty of Indiana University in 1961 as a lecturer in political science, and reached the rank of professor in 1976 . He also served as acting director of Indiana's Russian and East European Institute in 1988-89. His undergraduate course on Soviet/Russian politics was hugely popular, and his graduate seminars were among the reasons Indiana was such an important center for Soviet/Russian Studies. In addition, he was a frequent guest lecturer at other institutions, from Princeton and Columbia, to the universities of Bergen, Istanbul, Madrid, Oslo, and St. Petersburg. He also addressed a wide range of other audiences at, for instance, the CIA, the Kennan Institute, the USSR Academy of Sciences, and the Romanian Communist Party's Institute of Political Science.

$\mathrm{He}$ was much in demand as a speaker because of his deep and highly nuanced understanding of the Soviet/Russian political scene. His grasp of how the system worked, and his ability to explain the apparently chaotic and opaque and make it seem almost rational was valued by his students and colleagues alike. This understanding was also embodied in his published research. As might be expected of someone with such broad interests, his scholarship covered a wide range of issues, though the ones that most engaged him were the Soviet legal system (he had studied law at Leningrad State University while a graduate student), bureaucratic politics, and the politics of the Communist Party itself. He also had an enduring interest in the history of Russian political thought (he often taught a graduate seminar on this) that was another scholarly focus, and so was less surprised than many of us when philosophical currents from Russia's past reemerged in the late $1980 \mathrm{~s}$. This interest is reflected not only in several articles over the course of his long career but in his final book, Russian $\mathrm{Na}$ tionalism and the Legacy of Empire
(1996). He was also very well known as the author of the widely-used textbook, USSR: The Politics of Oligarchy $(1974,1986,1990)$, which has gone through three editions. He was working on a completely revised version on the politics of the Russian Federation at the time of his death.

His scholarship on Russia was enriched by his very frequent trips there, starting in the mid-1950s, and especially by his remarkable knack for finding himself at ground zero during events of great significance. Even as a graduate student doing dissertation research in 1960 , for instance, he found himself the lone American in the visitors' gallery of the Supreme Soviet when Nikita Khrushchev announced that Francis Gary Powers' U-2 plane had been shot down; he said he had never felt so lonely before or since in his entire life. Much later, he was also present during what he called the "comic opera putsch" of August 1991, as well as the tank assault on the parliament building in October of 1993; during the latter he managed to talk himself past guards and into the building so he could talk to the leaders of the insurrection. (Those who recall him as rather taciturn might be surprised at such salesmanship, but he often seemed a more animated speaker in Russian than in English, and something about the atmosphere in Russia seemed to invigorate him as well.)

The access he gained to Soviet and Russian officialdom over the course of many research visits also provided entrée to figures who have since become very prominent: Boris Yeltsin, for instance (who was vastly interested in the methods of Indiana's hog farmers); Gennadii Zyuganov (a "classic apparatchik" who was "cagey" on the subject of whether the Communist Party of the Russian Federation had inherited the CPSU's assets); Aleksandr Lebed ("amazingly inarticulate"); and Vladimir Zhirinovskii (who he thought clownish, but conveniently so for Yeltsin and company). Meeting Mikhail Gorbachev after the Soviet collapse, he was introduced as the author of a highly-regarded textbook on Soviet politics. Gorbachev looked at him, raised an eyebrow, and said gruffly, "So, Professor, did you predict the fall of the USSR?" Darrell's response: "No, Mr. President; did you?" Gorbachev started to glare, but gave up and burst into laughter.

Darrell also managed a very full life outside of the academy. At the center of it was his wife, Louise B. Hammer, also a member of the Indiana University faculty, and his two children, Rebekah and Owen. He was also active in local politics, serving as a Democratic precinct committee member for some 20 years, and even taught Sunday school for many years.

Darrell was always there for us, his former students, and became a loyal and supportive colleague, and friend as well. He will be greatly missed.

\section{Andrea Stevenson Sanjian Bucknell University \\ Gordon B. Smith University of South Carolina}

\section{Charles H. Longley}

Charles H. Longley, professor of political science at Bucknell University, died on October 23, 1998, at the age of 59 , after an illness of several months.

A graduate of Union College, he held his Ph.D. from the University of North Carolina, Chapel Hill. Since 1967, he taught political science at Bucknell, served several times as chair of the department, and served the university as its prelaw adviser for the last 30 years. A beloved teacher, he received the university's Lindback Distinguished Teaching Award in 1986. The lives of several generations of Bucknell students were enriched by Chuck's contributions as teacher and adviser.

Chuck was a close student of American political institutions, with particular attention to Congress and the judicial system. He was also an expert of the party reform movement of the early 1970 s, embodied in the McGovern Commission of the Democratic Party. Most recently, he combined his interest in American political institutions with his abiding 